Article

\title{
Chitosan Rate of Uptake in HEK293 Cells is Influenced by Soluble versus Microparticle State and Enhanced by Serum-Induced Cell Metabolism and Lactate-Based Media Acidification
}

\author{
Caroline D. Hoemann *, Jessica Guzmán-Morales, Nicolas Tran-Khanh, Geneviève Lavallée, \\ Mario Jolicoeur and Marc Lavertu
}

Department of Chemical Engineering, Institute of Biomedical Engineering, FRQS Groupe de Recherche en Sciences et Technologies Biomédicales (GRSTB), Ecole Polytechnique, 2900 Blvd. Edouard Montpetit, Montreal, Quebec, H3T 1J4, Canada; E-Mails: jessica.guzman-morales@polymtl.ca (J.G.-M.); nicolas.tran-khanh@polymtl.ca (N.T.-K.); gennygenlavallee@hotmail.com (G.L.); mario.jolicoeur@polymtl.ca (M.J.); marc.lavertu@polymtl.ca (M.L.)

* Author to whom correspondence should be addressed; E-Mail: caroline.hoemann@polymtl.ca; Tel.: +1-514-340-4848; Fax: +1-514-340-2980.

Received: 16 November 2012; in revised form: 30 December 2012 / Accepted: 7 January 2013 / Published: 15 January 2013

\begin{abstract}
Chitosan is a biocompatible polysaccharide composed of glucosamine and $\mathrm{N}$-acetylglucosamine. The polymer has a unique behavior of fluctuating between soluble chains at $\mathrm{pH} 6$ and insoluble microparticles at $\mathrm{pH}$ 7. The purpose of this study was to test the hypothesis that chitosan structure, solubility state, and serum influence the rate of cell uptake. Chitosans with $80 \%$ and $95 \%$ degree of deacetylation (medium and low viscosity) were tagged with rhodamine and analyzed for particle size, media solubility, and uptake by HEK293 epithelial cells using live confocal microscopy and flow cytometry. In media pH 7.4 with or without $10 \%$ serum, chitosans fully precipitated into 0.5 to $1.4 \mu \mathrm{m}$ diameter microparticles with a slight negative charge. During $24 \mathrm{~h}$ of culture in serum-free medium, chitosan particles remained extracellular. In cultures with serum, particles were taken up into intracellular vesicles in a serum dose-dependent manner. Opsonization of chitosan with serum, or replacement of serum by epidermal growth factor (EGF) failed to mediate serum-free chitosan particle uptake. Serum stimulated cells to acidify the media, partly by lactate generation. Media acidified to $\mathrm{pH} 6.5$ by $7 \mathrm{mM}$ lactate maintained $50 \%$ of chitosan in the soluble fraction, and led to minor uniform serum-free uptake in small vesicles. Conclusion: Media acidification mediates minor in vitro uptake of non-biofouled soluble
\end{abstract}


chitosan chains, while serum-biofouled insoluble chitosan microparticles require sustained serum exposure to generate energy required for macropinocytosis.

Keywords: chitosan; HEK293 cells; lactate; EGF; serum; confocal microscopy; microparticle

\section{Introduction}

Chitosan (Figure 1) is a mucoadhesive polysaccharide with wide-ranging applications in drug delivery, gene delivery, vaccines, and tissue engineering [1,2]. The mode of delivery, site of action, biodegradation, and cell/tissue responses to chitosan are tightly linked to the polymer structure. Chitosan is derived from chitin, $\beta(1-4)$ - $O$-linked $N$-acetyl- $\beta$-D-glucosamine (GlcNA), the insoluble backbone component of shrimp and crab shells, by chemical deacetylation. Depending on the degree of deacetylation (DDA), chitosan can have an average glucosamine content that ranges from $\sim 45 \%$ to $100 \%$ (Figure 1). Chitosan is soluble at $\mathrm{pH} 6$, where glucosamine carries a minimal $\sim 40 \%$ positive charge state [3], and insoluble at $\mathrm{pH} 7$, except for chitosans with very low DDA ( $\sim 50 \%$ DDA) [4] or very low molecular weight (chitosan oligomers, $<3,000 \mathrm{Da})[5,6]$.

Figure 1. Chemical structure of chitosan, a polysaccharide with heterogeneous GlcNA content.

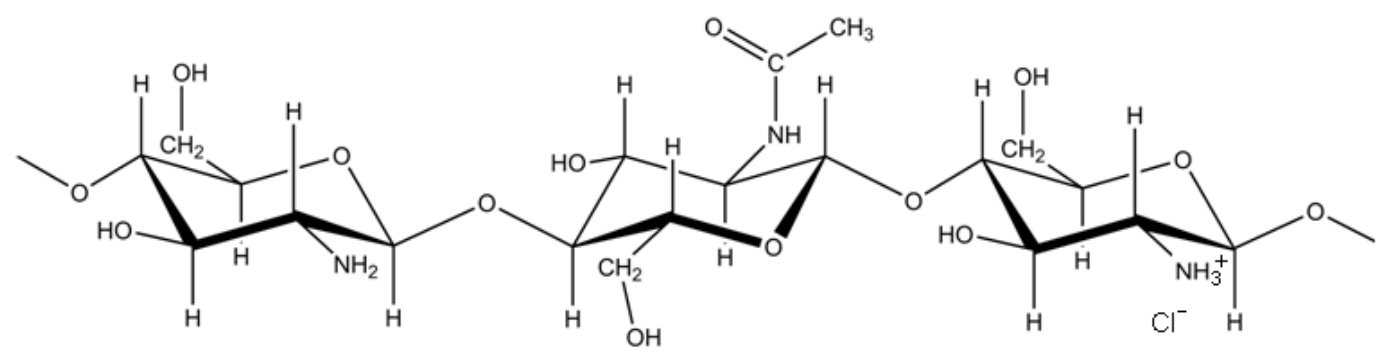

Enzymatic degradation of chitosan by serum lysozyme requires three consecutive GlcNA residues to hydrolyze the sugar linkages [7]. Highly deacetylated chitosans ( $>90 \%$ DDA) are non-biodegradable [8] and slightly cytotoxic [9], while more acetylated chitosans (50\% to $85 \%$ DDA) are biodegradable, and attract neutrophils and macrophages which phagocytose and degrade the polymer [8,10-13]. After becoming hydrolyzed to ultra-low molecular weight $(<10,000 \mathrm{Da})$, chitosan chains pass across the intestinal epithelial barrier [14] and become excreted in urine [4]. In the context of drug delivery, chitosan is often used as a nanoparticle [9,15] or a soluble PEGylated form [16]. In the context of regenerative medicine and vaccination adjuvants, chitosan is often applied or implanted as a slightly acidic solution [17,18], microparticles [19], or insoluble scaffolds [8].

Our specific interest in studying chitosan-cell interactions occurs in the context of regenerative medicine, where therapeutic effects on bone and cartilage repair were obtained using an implant composed of blood clot interspersed with insoluble chitosan microparticles $(80 \%$ DDA, medium viscosity) [20]. The bio-engineered chitosan-blood clot can be injected and coagulated in situ in a surgically treated cartilage lesion, using medium viscosity chitosan solutions whereas low-viscosity chitosan solutions generate runny blood mixtures that can only be implanted after pre-solidifying ex vivo [21]. Others have used viscous acetic acid chitosan solutions applied to bleeding tissues as a 
hemostatic, which is predicted to generate insoluble microparticles at blood $\mathrm{pH}$ [17]. Chitosan-based gene therapy also requires co-delivery of insoluble chitosan microparticles [22-24]. Examples of biomedical uses of chitosan as insoluble microparticles are summarized in Table 1.

Table 1. Insoluble chitosan microparticles: Published examples of in vivo biomedical use, and in vitro investigation of cell responses.

\begin{tabular}{|c|c|c|}
\hline $\begin{array}{l}\text { Method of insoluble chitosan } \\
\text { microparticle preparation }\end{array}$ & Chitosans analyzed & Application \\
\hline \multicolumn{3}{|c|}{ Neutral precipitation of acid-soluble chitosan in vivo or in vitro } \\
\hline \multirow{2}{*}{$\begin{array}{l}\text { Mix acid-soluble chitosan solution or } \\
\text { chitosan-glycerol phosphate solution } \\
\text { pH 4-6.8 with whole blood and/or } \\
\text { directly apply to bleeding tissues }\end{array}$} & $80 \%$ DDA & Hemostatic in vivo [17] \\
\hline & $\begin{array}{l}75 \%-82 \% \mathrm{DDA} \\
150-250 \mathrm{kDa}\end{array}$ & $\begin{array}{l}\text { Bone and articular cartilage repair } \\
\text { in vivo }[20]\end{array}$ \\
\hline \multirow{3}{*}{$\begin{array}{l}\text { Inject mixtures of chitosan-DNA, with } \\
\text { a molar excess of chitosan, in } \\
\text { intramuscular, subcutaneous sites }\end{array}$} & $92 \% \mathrm{DDA}, 10 \mathrm{kDa}$ & Gene delivery in vivo [24] \\
\hline & $80 \%$ DDA, $10 \mathrm{kDa}$ & \\
\hline & $80 \% \mathrm{DDA}, 80 \mathrm{kDa}$ & \\
\hline \multirow{4}{*}{$\begin{array}{l}\text { Combine soluble chitosan at } 5 \text { - to } \\
10 \text {-fold molar excess with DNA, } \\
\text { pipette into cell culture medium } \\
\text { DMEM+10\% serum pH } 7.6\end{array}$} & $80 \%$ DDA, $15 \mathrm{kDa}$ & In vitro DNA delivery: A549, Hela, \\
\hline & $92 \% \mathrm{DDA},>100 \mathrm{kDa}$ & B16 cells, HEK293 cells $[25,26]$ \\
\hline & $94 \%$ DDA, $52 \mathrm{kDa}$ & \\
\hline & & \\
\hline \multirow{5}{*}{$\begin{array}{l}\text { Pipette acid-soluble chitosan } \\
\text { pH } 5.0 \text { into basal media } \mathrm{pH} 7.6 \\
\text { (DMEM, } \alpha \text { MEM, RPMI } \pm 10 \% \text { to } 16 \% \\
\text { fetal bovine serum) }\end{array}$} & $80 \% \mathrm{DDA}, 179 \mathrm{kDa}$ & $\begin{array}{l}\text { In vitro bone marrow stromal cell } \\
\text { osteogenesis [27] }\end{array}$ \\
\hline & $81 \%$ DDA, $35 \mathrm{kDa}$ & In vitro macrophage activation [28] \\
\hline & $80 \% \mathrm{DDA}, 179 \mathrm{kDa}$ & In vitro neutrophil chemotaxis, \\
\hline & $95 \% \mathrm{DDA}, 168 \mathrm{kDa}$ & degranulation, chitosan uptake [14] \\
\hline & $92 \% \mathrm{DDA}, 10 \mathrm{kDa}$ & $\begin{array}{l}\text { In vitro chitosan-HEK } 293 \text { cell } \\
\text { adsorption/uptake [26] }\end{array}$ \\
\hline \multicolumn{3}{|l|}{ Pre-formed chitosan microparticles } \\
\hline \multirow{2}{*}{$\begin{array}{l}\text { Pre-formed microparticles } \\
\text { (glutaraldehyde and Tween surfactant) } \\
\text { injected into the mouse foot pad or } \\
\text { added to DMEM+heat-inactivated } \\
10 \% \text { fetal bovine serum }\end{array}$} & $\begin{array}{l}75 \%-85 \% \text { DDA, } \\
164 \mathrm{kDa}\end{array}$ & $\begin{array}{l}\text { Vaccine, lymph node trafficking } \\
\text { in vivo [29] }\end{array}$ \\
\hline & & $\begin{array}{l}\text { In vitro HEK293, A549, RAW264 } \\
\text { cell uptake [29] }\end{array}$ \\
\hline $\begin{array}{l}1 \mu \mathrm{m} \text { or } 3.5 \mu \mathrm{m} \text { pre-formed chitosan } \\
\text { microparticles added to RPMI }+10 \% \\
\text { serum, } \mathrm{pH} 7.2\end{array}$ & $\geq 80 \% \mathrm{DDA}$ & $\begin{array}{l}\text { Wound-repair applications: in vitro } \\
\text { neutrophil chemotaxis [30] in vitro } \\
\text { macrophage activation [31] }\end{array}$ \\
\hline
\end{tabular}

Little information is available on conditions that control chitosan microparticle uptake by non-phagocytic cells, however several in vitro studies indicate a role for serum. Fluorescent chitosans with broad structural characteristics ( $46 \%$ to $92 \%$ DDA, 10-213 kDa) showed negligible uptake in serum-free media, by several epithelial cell types $[9,15,32,33]$, even when media was adjusted to $\mathrm{pH} 6.5$ below the intrinsic $\mathrm{p} K_{\mathrm{a}}\left(\mathrm{p} K_{0} \sim 6.7\right)$ of chitosan [3], to favor polymer solubility via positive charge state. But these studies used chitosan tagged with fluorescein, which is quenched at acidic $\mathrm{pH}$, and live cell chitosan uptake could not be directly monitored or quantified. In other studies using rhodamine-labeled chitosan, an acid-resistant fluorophore (Figure 2) [34], a variety of cell types 
internalized chitosan in serum-containing media: primary bone marrow stromal cells, neutrophils, bone marrow monocyte-derived macrophages, and HEK293 cells [13,22,26-28]. One study suggested that 92\% DDA, $10 \mathrm{kDa}$ chitosan can be internalized by HEK293 cells with or without serum, but the conclusions were only based on flow cytometry data and for only one particular chitosan [26]. A systematic study of the effect of chitosan structure on microparticle uptake by cells, with or without serum, is currently lacking.

Figure 2. Chemical structure of RITC-chitosan.

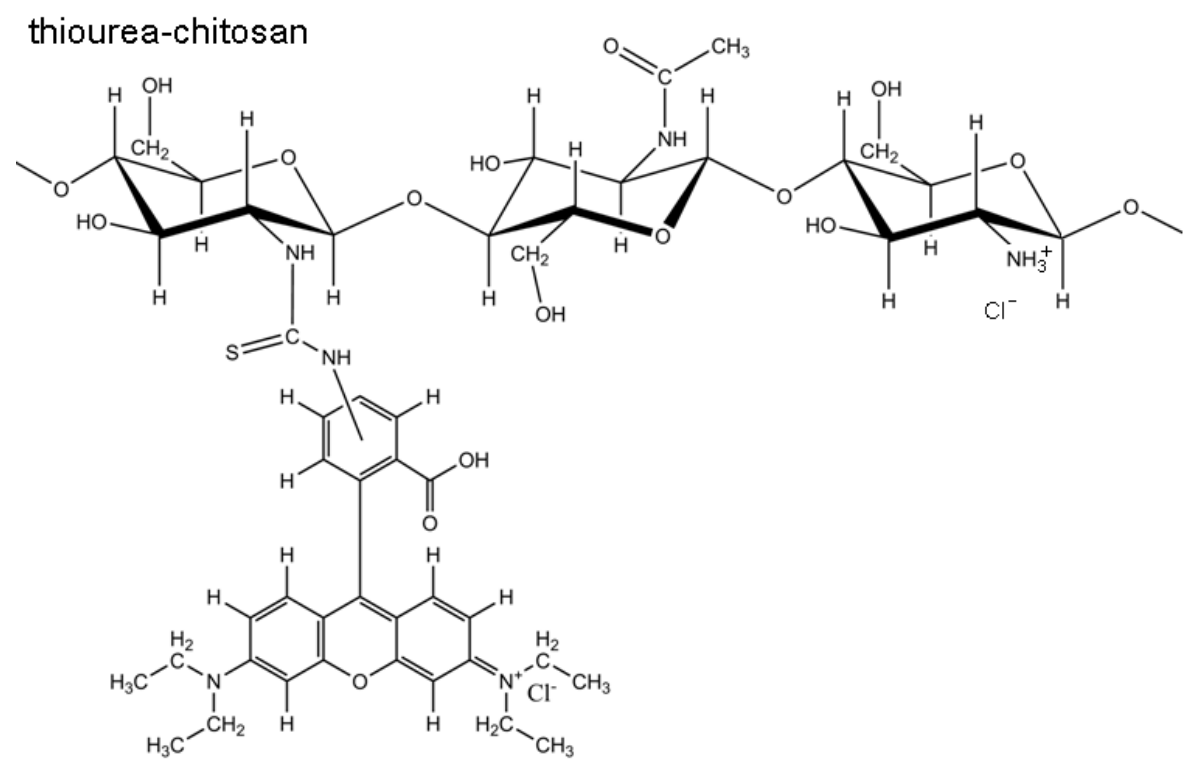

Exposure of a biomaterial to serum will lead to "biofouling", or natural adsorption or deposition of biological factors from the environment onto the biomaterial surface. Cationic chitosan chains were previously shown to be selectively "biofouled" with anionic serum proteins, including highly abundant serum albumin ( $\sim 40 \mathrm{mg} / \mathrm{mL}$ in serum, pI 5.7) [35] and complement $\mathrm{C} 3(\sim 1 \mathrm{mg} / \mathrm{mL}$ in serum, pI 6.0) [36]. Complex formation with $\mathrm{C} 3$ and other serum factors has an unclear influence on chitosan-cell interactions. It is well-established that $\leq 200 \mathrm{~nm}$ diameter chitosan nanoparticles (chitosan condensed into polyplexes with DNA or polyphosphate) are readily internalized with and without serum, especially at acidic $\mathrm{pH}[9,26,37]$. The purpose of this study was to systematically analyze the effect of chitosan structure on chitosan microparticle formation and uptake in live cells, using HEK293 cells, a transformed epithelial human cell line with a high endocytotic capacity. Four structurally distinct chitosans were specifically labeled at 1 rhodamine tag per 200 monomers (i.e., $0.5 \%$ mol rhodamine isothiocyanate, RITC/mol chitosan) [33], which minimally alters DDA level and molecular weight, and allows direct, quantitative comparison by flow cytometry. We tested the hypothesis that $N$-acetylglucosamine (GlcNA) content and serum influence the rate of cell uptake.

\section{Results and Discussion}

\subsection{Structural Characterization of RITC-Chitosan and RITC-Chitosan Microparticles}

Four chitosans were used to generate a library of fluorescent derivatives for cell-uptake studies, at $95 \%$ DDA or $80 \%$ DDA and medium or low viscosity, while another $82 \%$ DDA chitosan was used for 
structural analyses before and after rhodamine tagging (Table 2). Photoacoustic Fourier Transform Infrared (FT-IR) spectroscopy confirmed structural differences in the library of four chitosans prior to derivatization (Figure 3A), and demonstrated covalent linkage of RITC to 82M chitosan (Figure 3B).

Table 2. RITC-chitosans used in the study.

\begin{tabular}{|c|c|c|c|c|c|}
\hline chitosan & $\begin{array}{l}\text { Viscosity } \\
(m P a . s)^{\wedge}\end{array}$ & $\begin{array}{l}\text { Chitosan } \\
\text { DDA (\%) \# }\end{array}$ & $M_{n}(k D a)$ & $P D I\left(M_{w} / M_{n}\right)$ & $\begin{array}{l}\text { RITC/chitosan } \\
\% \mathrm{~mol} / \mathrm{mol}\end{array}$ \\
\hline RITC-95M * & 2,964 & 94.6 & 177 & 1.1 & 0.6 \\
\hline RITC-95L * & 197 & 94.6 & 102 & 1.2 & 0.6 \\
\hline RITC-80M * & 1,422 & 80.6 & 144 & 1.3 & 0.5 \\
\hline RITC-80L * & 178 & 80.2 & 108 & 1.5 & 0.5 \\
\hline RITC-82M ** & N.D. & 81.7 & 241 & 1.1 & 0.9 \\
\hline
\end{tabular}

$\wedge 2.05 \% \mathrm{w} / \mathrm{w} \mathrm{HCl}$ solution $\mathrm{pH} 5.6$ and \# \%DDA prior to RITC-labeling $M n$ : number-average molecular weight. PDI: polydispersity index; N.D.: not done; * used for particle size, chitosan solubility, cell uptake; ** used for FT-IR (Figure 3B).

Figure 3. FT-IR spectra of the chitosan library prior to RITC coupling (A), and RITC-82M chitosan vs. 82M chitosan-only and 82M chitosan mixed with RITC without coupling (B). Chitosans were analyzed in the $\mathrm{HCl}$ salt conjugate form (A) or free base form (B). 95: 95\%DDA; 80: 80\%DDA; 82: 82\%DDA; M: medium viscosity; L: low viscosity.
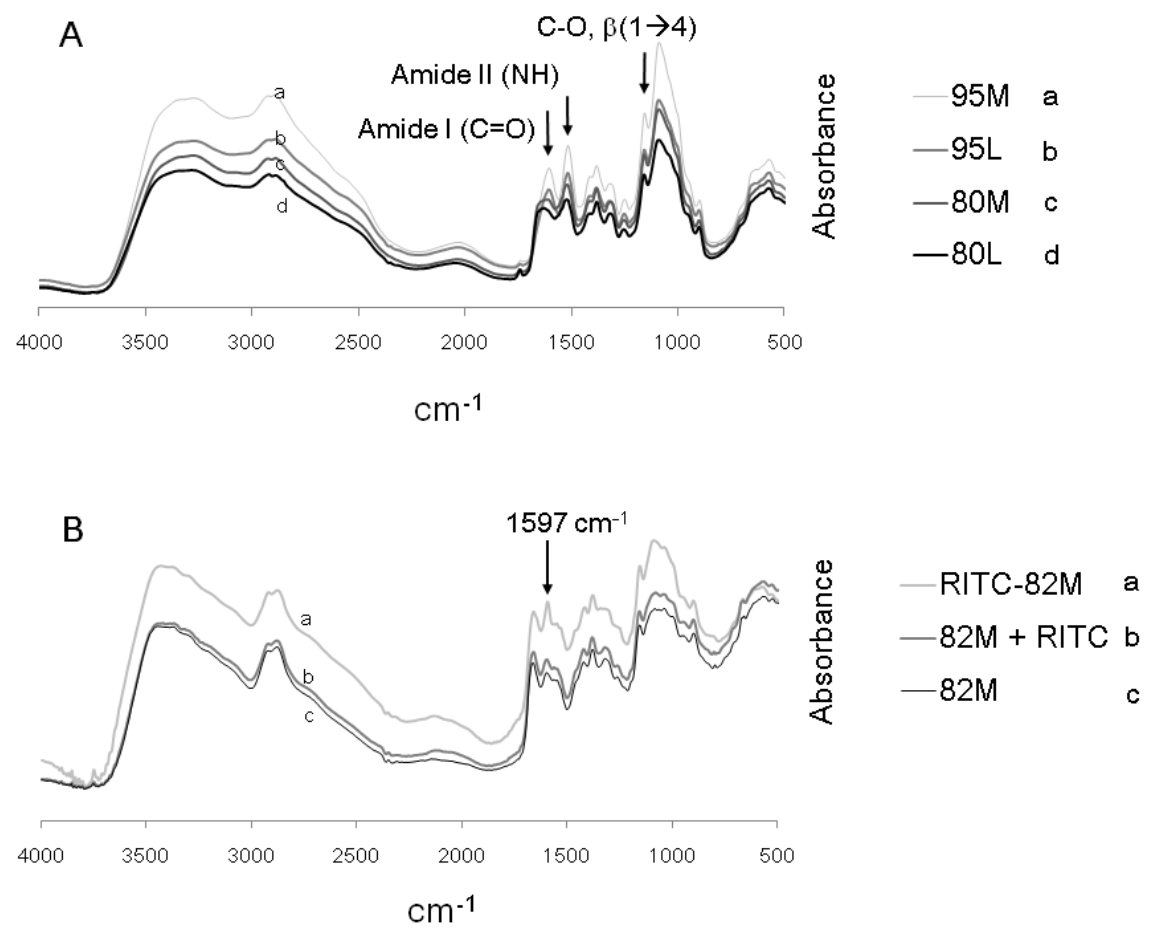

By FT-IR, chitosans $80 \mathrm{M}$ and $80 \mathrm{~L}$ had a diminished amide II peak ( $\mathrm{NH}$ bending in Glc, $1561 \mathrm{~cm}^{-1}$ ) and a broader amide $\mathrm{I}$ peak $\left(\mathrm{C}=\mathrm{O}\right.$ carbonyl stretching in $\left.\mathrm{GlcNA}, \sim 1640 \mathrm{~cm}^{-1}\right)$ compared to $95 \mathrm{M}$ and 95L (Figure 3A). The amide I peak can appear as a doublet at $1663 \mathrm{~cm}^{-1}$ and $1626 \mathrm{~cm}^{-1}$ when 2 types of intermolecular H-bonding are involved with the carbonyl group [38]. Higher molecular weight chitosan (95M vs. 95L, and 80M vs. 80L) showed relative intensification of the $\beta(1-4) O$-linkage peak at $1159 \mathrm{~cm}^{-1}$ (C-O stretch) [38,39] (Figure 3A). The strong $1597 \mathrm{~cm}^{-1}$ peak in RITC-82M chitosan 
(arrow, Figure 3B) is consistent with a new thiourea linkage between RITC and the amine group of the glucosamine monomer.

RITC-chitosans pipetted into serum-free medium $\mathrm{pH} 7.4$ rapidly formed $>99 \%$ insoluble microparticles (DMEM, Figure 4A), with an average hydrodynamic diameter of $\sim 0.5 \mu \mathrm{m}(80 \mathrm{M}, 80 \mathrm{~L})$ or $\sim 1.4 \mu \mathrm{m}(95 \mathrm{M}, 95 \mathrm{~L}$, Figures $4 \mathrm{C}$ and $5 \mathrm{~A})$, and a slight negative charge ( -2 to $-3.7 \mathrm{mV}$, Figure $5 \mathrm{~B})$. RITC-chitosans pipetted into medium with $10 \%$ serum $\mathrm{pH} 7.4$ also precipitated, with a slight but significant $\sim 3 \%$ increase in neutral solubility for $80 \mathrm{M}$ and $80 \mathrm{~L}$ but not $95 \mathrm{M}$ and $95 \mathrm{~L}(p<0.0001, \mathrm{~N}=6$, Figure 4A). Rhodamine B fluorescence was maintained in all cell culture media, but depressed in media $\mathrm{pH} 7.4$ compared to water, and enhanced by serum and acid pH (Figure 4B). In medium with $10 \%$ serum, RITC-chitosan formed polydisperse electronegative $(-2.5 \mathrm{mV})$ microparticles with average diameters of $\sim 1.0 \mu \mathrm{m}(80 \mathrm{M}, 80 \mathrm{~L})$ and $\sim 1.5 \mu \mathrm{m}(95 \mathrm{M}, 95 \mathrm{~L})$, along with new nanoparticle peaks (Figures 4D and 5).

Figure 4. Residual neutral-soluble RITC-chitosan fluorescence in media $\mathrm{pH} 7.4$ vs. RITC-chitosan fluorescence in water pH 5.6 defined as $100 \%$ (A), \% rhodamine B fluorescence in culture media $v s$. in water defined as $100 \%(\mathbf{B})$, and hydrodynamic chitosan particle size distribution in DMEM pH 7.4 (C) and DMEM+10\% FBS pH 7.4 (D); Panel E shows 95M in DMEM+10\% FBS (red line) compared to media-alone (DMEM+10\% FBS, black line).
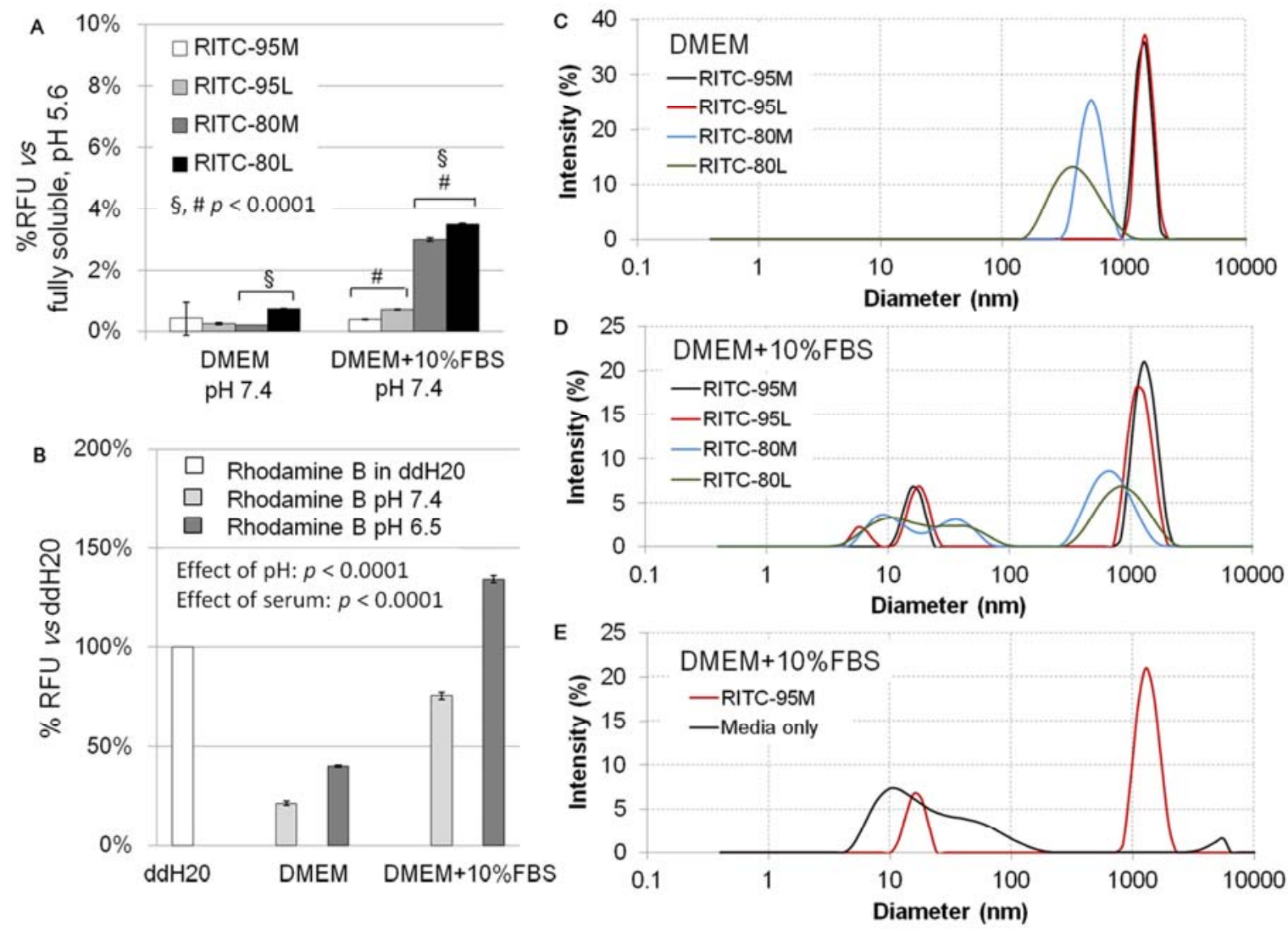

Media-alone with 10\% serum contained particles ranging from 7 to $100 \mathrm{~nm}$ (black line, Figure 4E) with a negative zeta potential $(-8 \mathrm{mV}$, Figure $5 \mathrm{~B})$. These data are compatible with the hydrodynamic diameter $(7 \mathrm{~nm})$ of BSA and anionic charge state at neutral $\mathrm{pH}$ [40]. Note that BSA is present at around 80 -fold excess over RITC-chitosan in the samples with $10 \%$ serum and $50 \mu \mathrm{g} / \mathrm{mL}$ chitosan. 
Addition of chitosan to media with $10 \%$ serum reproducibly reversed the electronegative zeta potential reading (Figure 5B).

Figure 5. Average hydrodynamic diameter of the chitosan library with and without serum (A) and zeta potential of $50 \mu \mathrm{g} / \mathrm{mL}$ RITC-95M or RITC-80M chitosan in media without and with $10 \%$ serum $(\mathrm{N}=3$ to 4 measures, mean \pm standard deviation, B).

A

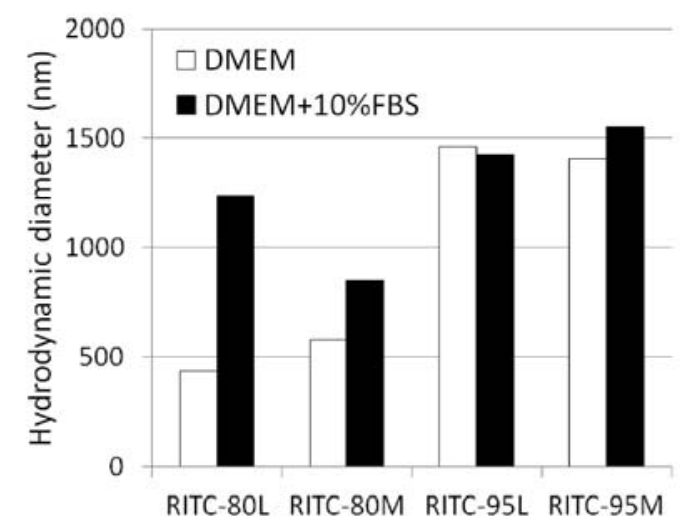

B

medium: DMEM DMEM+10\%FBS

RITC-chitosan: $95 \mathrm{M} 80 \mathrm{M} \quad--95 \mathrm{M} 80 \mathrm{M}$

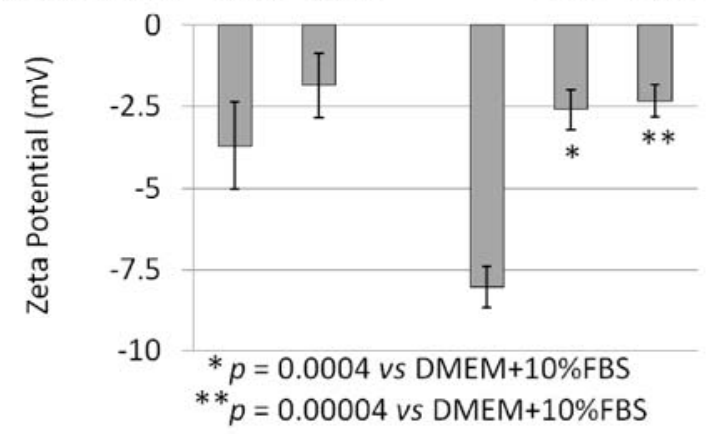

To summarize, dynamic light scattering (DLS) measures show that chitosan formed $0.2 \mu \mathrm{m}$ to $2 \mu \mathrm{m}$ insoluble microparticles and microparticle aggregates at $\mathrm{pH} 7.4$, with and without serum. In serum-free medium, chitosan microparticles are potentially complexed with anionic media salts or other anionic components (amino acids). In culture medium with serum and chitosan, small particles $(<100 \mathrm{~nm})$ represent mainly serum proteins, a fraction of which are most probably complexed with individual chitosan chains along with larger chitosan microparticle aggregates $(>200 \mathrm{~nm})$ that are expected to be partly complexed with anionic serum factors $[35,36]$.

\subsection{Serum Stimulates RITC-Chitosan Microparticle Uptake}

Live confocal microscopy showed that in DMEM-only, RITC-chitosan particles collected on the cell surface without being internalized after $24 \mathrm{~h}$ of culture (Figure 6A-B). Only rare vesicular RITC-chitosan uptake was seen in DMEM pH 7.4 (arrowhead, Figure 6B). In medium with 10\% FBS, all 4 RITC-chitosans became readily internalized in 0.1 to $2 \mu \mathrm{m}$ diameter vesicles (arrowheads, example images of RITC-80M Figure 6C-D and RITC-95M, Figure 6F). Cells exposed to free rhodamine B showed a faint staining pattern (Figure 6G vs. 6E), similar to the mitochondrial stain previously reported for porcine kidney proximal tubule cells exposed to $0.1 \mu \mathrm{g} / \mathrm{mL}$ rhodamine $\mathrm{B}$ in serum-containing medium [41]. Because RITC-chitosan was detected in intracellular vesicles while free rhodamine B fluorophore became associated with structures resembling mitochondria, this showed that the fluorescent signal observed inside cells was intact RITC-chitosan and not hydrolyzed fluorophore. 
Figure 6. Confocal images of HEK293 cells cultured for $24 \mathrm{~h}$ with $80 \mathrm{M}$ RITC-chitosan in DMEM pH 7.4 (A-B) or DMEM 10\% FBS pH 7.4 (C-D) (3-D reconstructions). Panels E-G show HEK293 cells in media with 10\% FBS (E) incubated $24 \mathrm{~h}$ with 95M RITC-chitosan (F) or rhodamine B (G). After chitosan uptake, cells were labeled with calcein AM (green live cell cytosol) and Hoechst 33342 (blue cell nuclei). Arrowheads: intracellular chitosan; arrows: extracellular chitosan. Open arrowheads: rhodamine B.
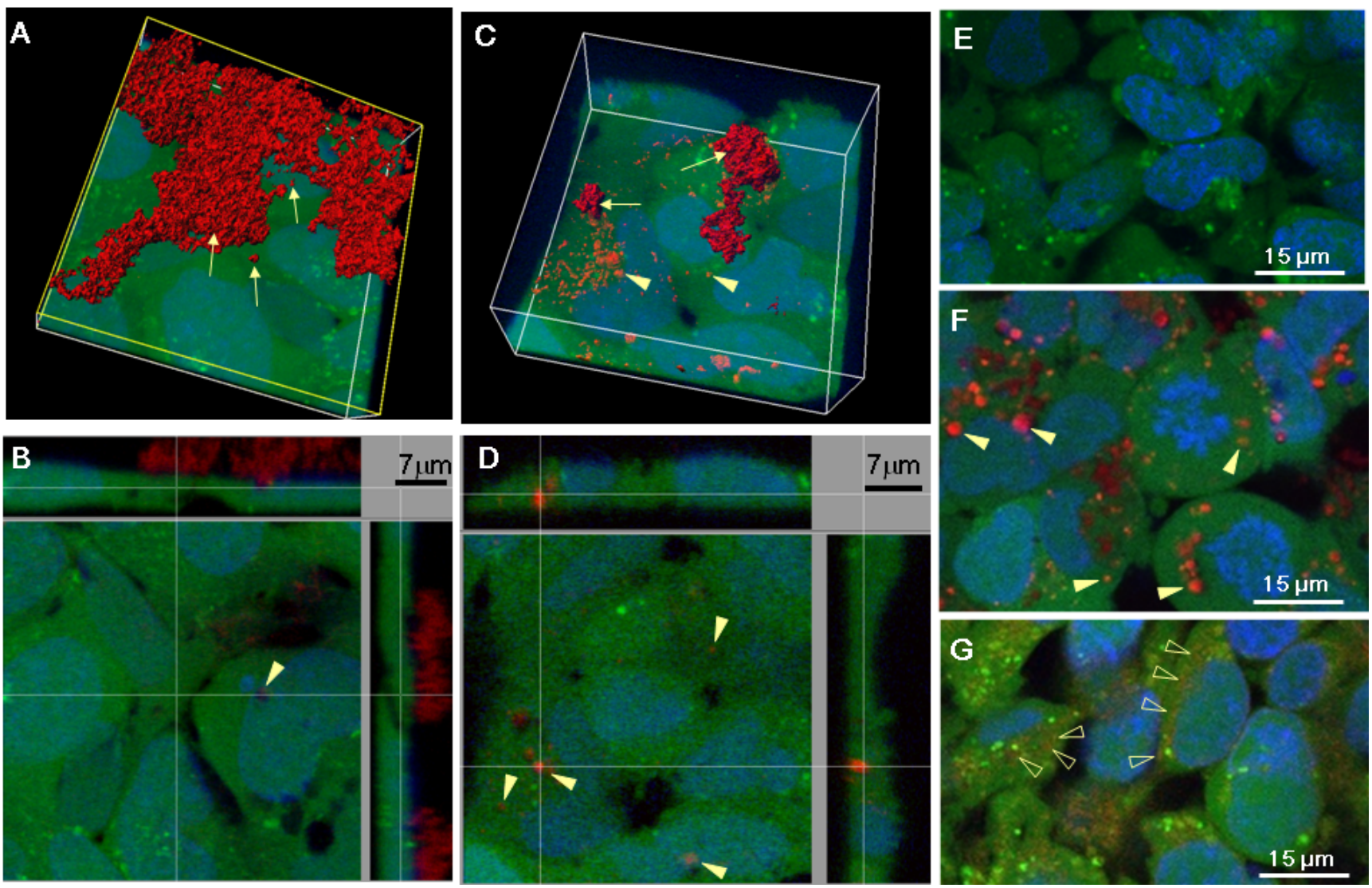

When analyzed by flow cytometry, cells incorporated more 95\% DDA than $80 \%$ DDA chitosan after $4 \mathrm{~h}$ of culture with $10 \%$ serum ( $p=0.00014$, Figure 7A-D,I). Similar DDA-dependent uptake was previously reported for chitosan-polyphosphate nanoparticles in A549 cells after $4 \mathrm{~h}$ in a serum-free balanced salt solution [9]. However the data could have an artifact because in our experiments, highly insoluble $95 \mathrm{M}$ and $95 \mathrm{~L}$ chitosan particles were observed to settle more rapidly to the bottom of the petri. After $24 \mathrm{~h}$ of culture in 10\% serum, HEK293 cells internalized all four RITC-chitosans to the same high level (Figure 7E-I). Free rhodamine B fluorophore was rapidly incorporated in HEK293 cells with low and steady fluorescence at 4 and $24 \mathrm{~h}$ (white peak, Figure 7). Rhodamine B was added to the cell cultures at the same molar level as the RITC fluorophore in our chitosan derivatives. Therefore, the $\sim 200$-fold higher fluorescence in RITC-chitosan-fed cultures (Figure 7I) reflects uptake of more fluorophore attached to chitosan. Part of the higher RITC-chitosan fluorescence at $24 \mathrm{~h}$ could be due to acid-induced intensification of rhodamine B fluorescence in acidifying endosomes (Figure 4B). 
Figure 7. Flow cytometry analysis of rhodamine B and RITC-chitosan uptake after $4 \mathrm{~h}$ (A-D) or $24 \mathrm{~h}(\mathbf{E}-\mathbf{H})$ of culture in $10 \%$ FBS, for 4 structurally distinct chitosans (as indicated), and mean RFU values from $\mathrm{N}=3$ to 5 distinct experiments (I). For $\mathbf{A}-\mathbf{H}$ : Black peak: unlabeled cells; white peak: rhoB-labeled; grey peak: RITC-chitosan-labeled.
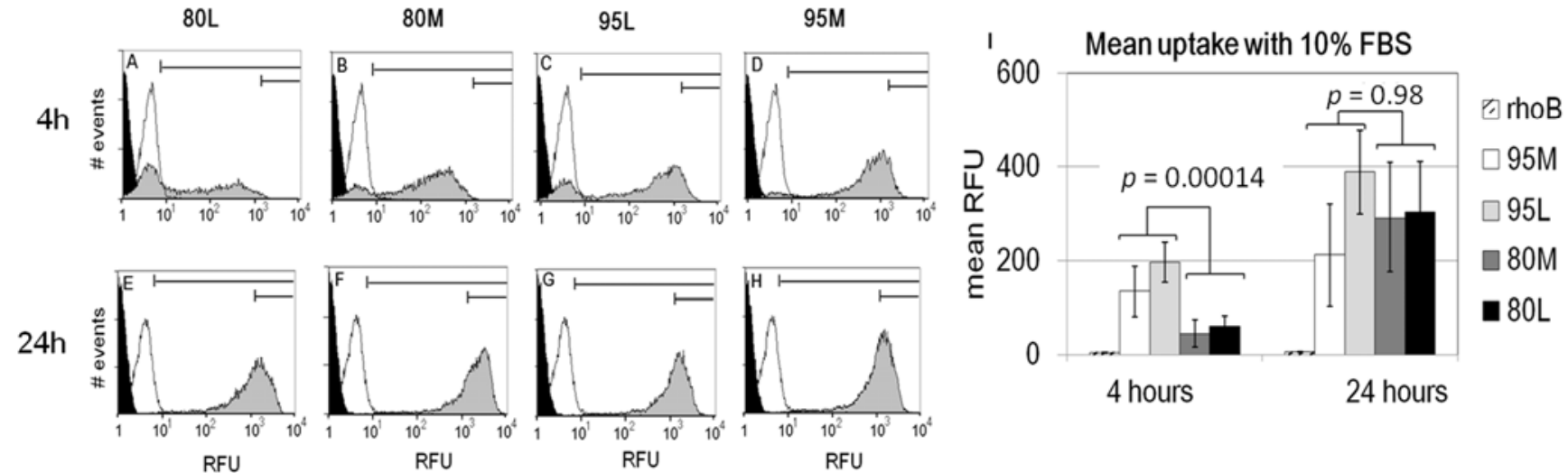

Cytospins of cells submitted to flow cytometry analysis showed that some of the signal for cells cultured in serum-free medium arose from RITC-chitosan adsorbed to the cell surface (arrows, Figure 8A). The contribution of extracellular signal was unavoidable, as trypan blue which is often used to mask extracellular fluorescein green fluorescence emission [32,42], is unable to mask extracellular rhodamine emission [26]. By comparison, cytospins of cells cultured with RITC-chitosan in 10\% serum showed abundant fluorescent intracellular vesicles (Figure 8B). These data allow us to conclude that high cell fluorescence after $24 \mathrm{~h}$ of culture is due to intracellular accumulation and not to more adsorption of RITC-chitosan to the cell surface. Taken altogether, these data confirm the hypothesis that DDA influences the rate of cell uptake (Figure 7I), but show that the delayed uptake of $80 \%$ DDA is a technical issue related to time required for the microparticles to collect on the monolayers.

Figure 8. Merged epifluorescent-brightfield images of cytospins of HEK293 cells submitted to flow cytometry after culturing 24 hours with RITC-80M in DMEM (A) or in DMEM+10\% FBS pH 7.4 (B). Red signal is RITC-chitosan, blue is Hoechst 33346-stained DNA. Symbols: arrows: extracellular RITC-80M adsorbed to cell surfaces as shown by the non-uniform microparticle shape; arrowhead: intracellular vesicles with RITC-chitosan.
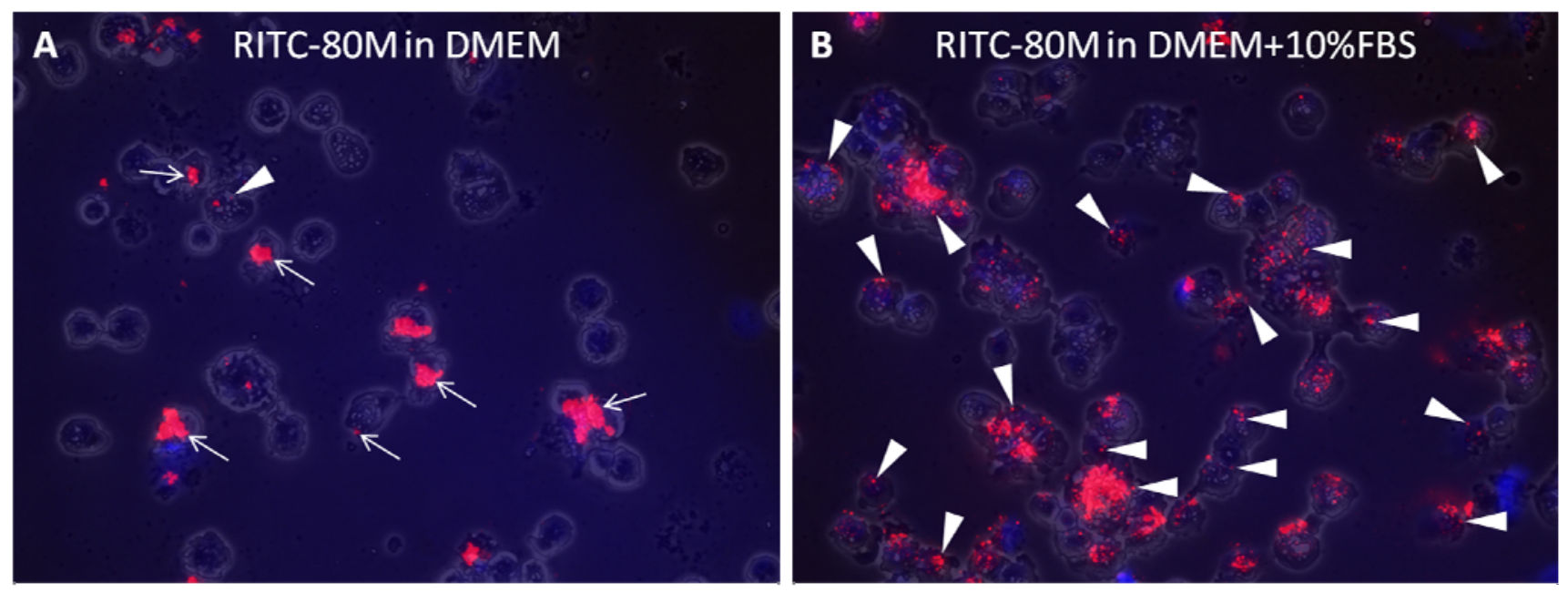


\subsection{Role of Serum and Lactate in Mediating Chitosan Uptake by HEK293 Cells}

Our data indicated that serum was necessary for chitosan uptake but did not fully explain why. It was previously shown that anionic serum proteins such as complement $\mathrm{C} 3$ associate selectively and non-covalently with chitosan, through electrostatic interactions [36]. We therefore tested the hypothesis that opsonization of chitosan microparticles by serum proteins is sufficient to promote chitosan microparticle uptake. However serum-opsonized chitosan particles were not internalized by HEK293 cells after 24 hours in serum-free media (Figure 9).

Figure 9. Flow cytometry profiles of cells exposed for $24 \mathrm{~h}$ to RITC-chitosan microparticles in DMEM (A), in DMEM+10\% FBS (B), or FBS-opsonized RITC-chitosan microparticles in DMEM (C). All media was pH 7.4. White peak: free rhodamine B; black peak: unlabeled HEK293 cells; light grey peak: RITC-95M; dark grey peak: RITC-80M.
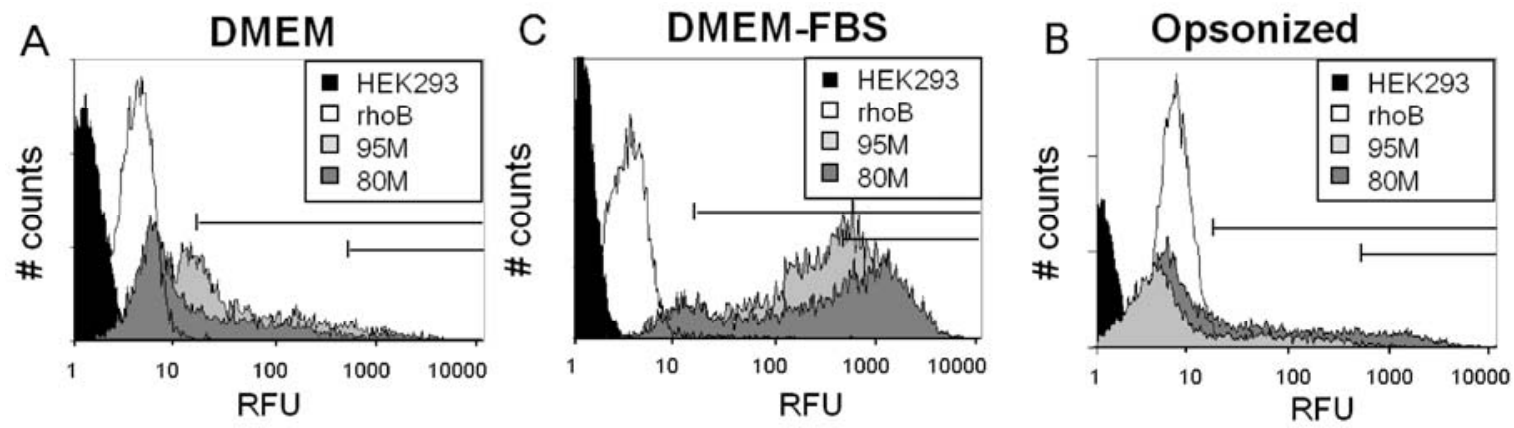

Confluent monolayers were observed to acidify the media after $24 \mathrm{~h}$ specifically in the presence of serum, from an initial $\mathrm{pH} \sim 7.6$ to final $\mathrm{pH} \sim 7.0$ (Figure 10A). These data suggested that serum was stimulating cells to produce more lactate. However after $24 \mathrm{~h}$ of culture, HEK293 cells generated the same levels of lactate $(\sim 7 \mathrm{mM}$ per million cells) and consumed a similar level of glucose $(5 \mathrm{mM})$ with and without serum (Figure 10B). The final lactate concentration was slightly higher in serum-containing conditioned media due to the presence of $1.9 \mathrm{mM}$ lactate in DMEM+10\% serum (dashed bar, Figure 10B). Exposure of cells to chitosan had no influence on glucose consumption or lactate generation (Figure 10B).

Figure 10. Media $\mathrm{pH}(\mathbf{A})$, and corresponding $7 \mathrm{mM}$ lactate generation and $5 \mathrm{mM}$ glucose consumption after $24 \mathrm{~h}$ of incubation at $37^{\circ} \mathrm{C}$ with and without serum (B). RITC-chitosan added to lactate-acidified media $\mathrm{pH} 6.5$ remained $30 \%$ to $50 \%$ soluble compared to RITC-chitosan fully soluble in dilute $\mathrm{HCl}$ pH $5.6(\mathbf{C})$.
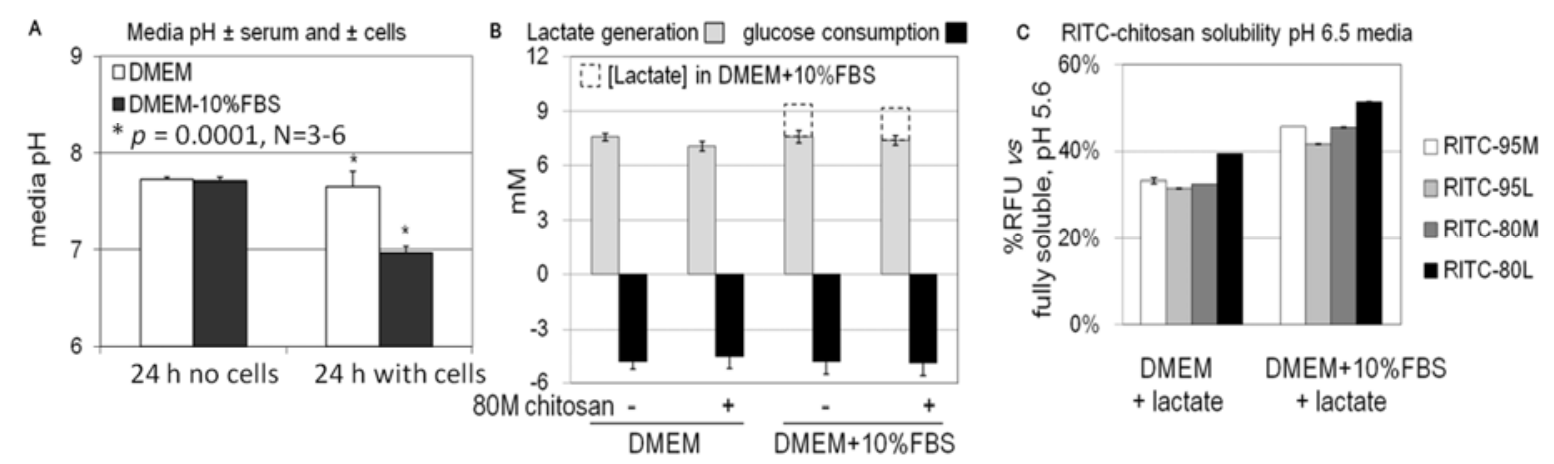
In other experiments, it was determined that addition of $7 \mathrm{mM}$ lactate to cell culture media (i.e., the same amount of lactate produced during $24 \mathrm{~h}$ by monolayer cells) reproducibly acidified the media by approximately $1 \mathrm{pH}$ unit, with or without $10 \%$ serum. The data seem to present a contradiction because $7 \mathrm{mM}$ lactate produced by cells cultured in DMEM for $24 \mathrm{~h}$ fails to generate a drop in media $\mathrm{pH}$. It should be noted however that the cell cultures are maintained under $5 \% \mathrm{CO}_{2}$ in media with a bicarbonate buffering system that helps neutralize the conditioned media $\mathrm{pH}$ and off-set the lactate production in DMEM.

To determine whether lactate could be directly influencing chitosan solubility and uptake, RITC-chitosan was pipetted into fresh lactate-acidified media $\mathrm{pH}$ 6.5. None of the chitosans fully precipitated, remaining $30 \%$ to $50 \%$ soluble at $\mathrm{pH} 6.5$, with or without serum (Figure 10C). The solubility data shown in Figure $10 \mathrm{C}$ are consistent with the chitosan intrinsic $\mathrm{p} K_{\mathrm{a}}$, which predicts around $50 \%$ solubility at $\mathrm{pH} 6.5$ in isotonic solutions [3].

When cells were exposed for $24 \mathrm{~h}$ to RITC-chitosan in lactate-acidified DMEM pH 6.5, according to quantitative flow cytometry, nearly all cells were labeled, but at very low levels (0-Lac, Figure 11A-B). When cells were exposed to RITC-chitosan in media containing $2 \%$ to $10 \%$ serum, a serum dose-dependent uptake was seen $(p<0.05$, Figure 11A-B). Heat-inactivated FBS, which is depleted of complement activity and a number of important chemokines and growth factors [43,44], slightly suppressed mean cell fluorescence after $24 \mathrm{~h}$ of uptake (RITC-80M), without influencing the percent cells labeled (Figure 11A-B). All of the cultures carried out with $2 \%$ to $10 \%$ serum at $\mathrm{pH} 7.4$ showed the same glucose consumption and slightly higher lactate generation than DMEM-only (Figure 11C). Lactate generation, however, did not correlate with chitosan uptake levels (Figure 11C vs. 11A).

Figure 11. Quantitative flow cytometry analysis of HEK293 cells (A-B, mean fluorescence and \% cells labeled), and lactate generation (C-D) after $24 \mathrm{~h}$ of culture with RITC-80M chitosan in media with different levels of serum $(0 \%, 2 \%, 5 \%, 10 \%)$, exogenous lactate or EGF. 10-Hi: 10\% heat-inactivated serum; 0-Lac, DMEM+7 mM lactate.

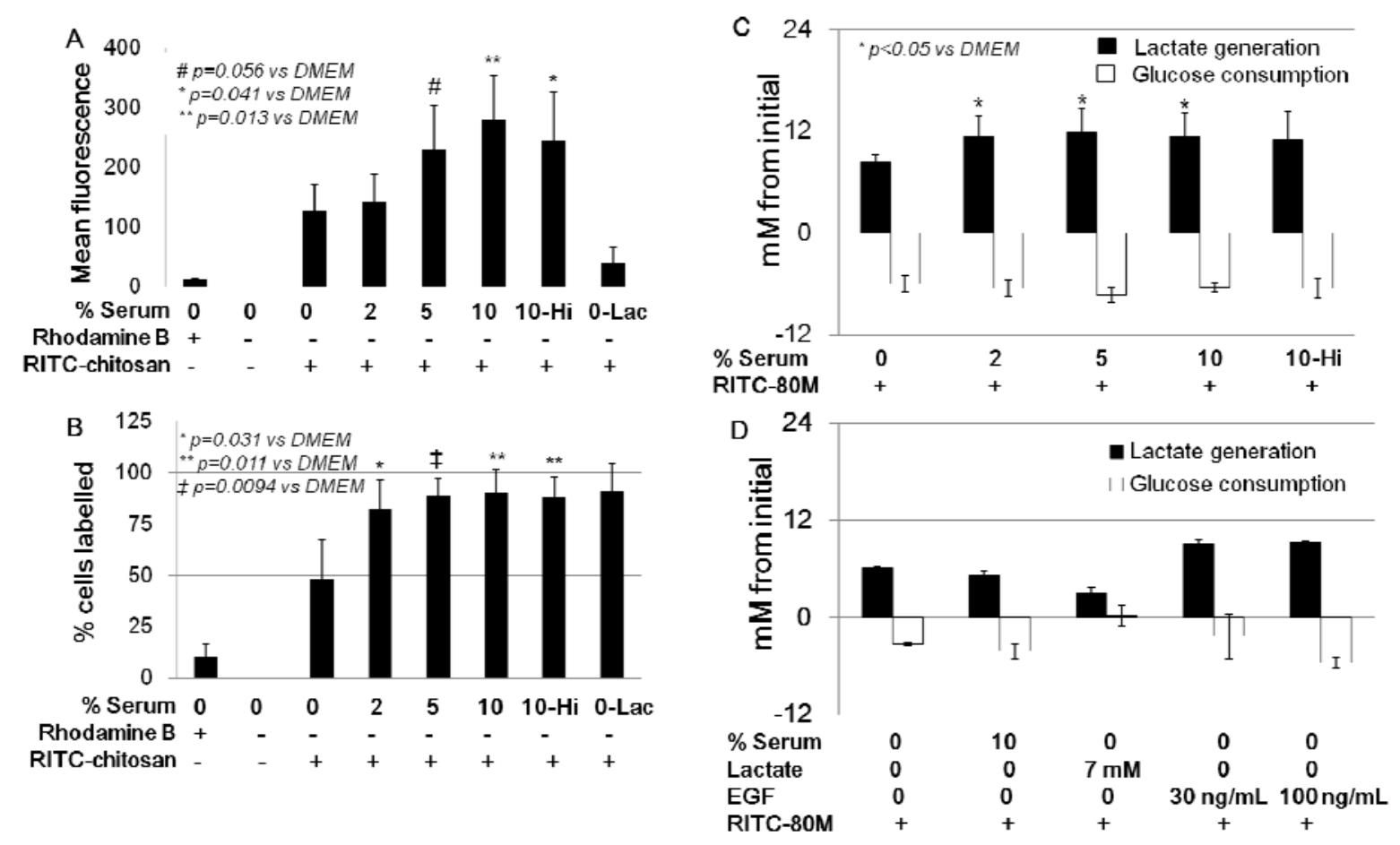


We next tested whether a heat-sensitive serum factor, such as epidermal growth factor (EGF) which stimulates Rac1-dependent macropinocytosis [45,46], could be sufficient to mediate chitosan microparticle uptake in serum-free media. Cells stimulated with $30 \mathrm{ng} / \mathrm{mL}$ or $100 \mathrm{ng} / \mathrm{mL}$ EGF in serum-free media $\mathrm{pH} 7.4$ showed increased lactate production $(9 \mathrm{mM}$ with EGF $v s . \sim 6 \mathrm{mM}$ for DMEM-only) and higher glucose consumption (5.3 $\mathrm{mM}$ with EGF vs. $3.3 \mathrm{mM}$ for DMEM-only, Figure 11D) but failed to internalize chitosan (Figure 12E-F). In other cultures, we tested the hypothesis that lactate alone can stimulate serum-free chitosan uptake. Exogenous lactate suppressed lactate generation (3.1 mM vs. $6 \mathrm{mM}$ for DMEM-only) and glucose consumption (0.2 $\mathrm{mM}$ vs. $3.3 \mathrm{mM}$, Figure 11D), and promoted RITC-chitosan uptake in very small vesicles in nearly all of the cells (Figure 12G-H).

Figure 12. Confocal images of HEK293 cells exposed to RITC-80M chitosan pipetted into media pH $7.4(\mathbf{A}-\mathbf{F})$ or lactate-acidified media $\mathrm{pH} 6.5(\mathbf{G}-\mathbf{H})$. Top panels: calcein AM (green live cells), Hoechst 33342 (blue cell nuclei) and RITC-80M chitosan particles (extracellular, white arrow; vesicle, arrowhead). Bottom panels: RITC-chitosan-only. Arrows: extracellular chitosan. Arrowheads: intracellular chitosan.

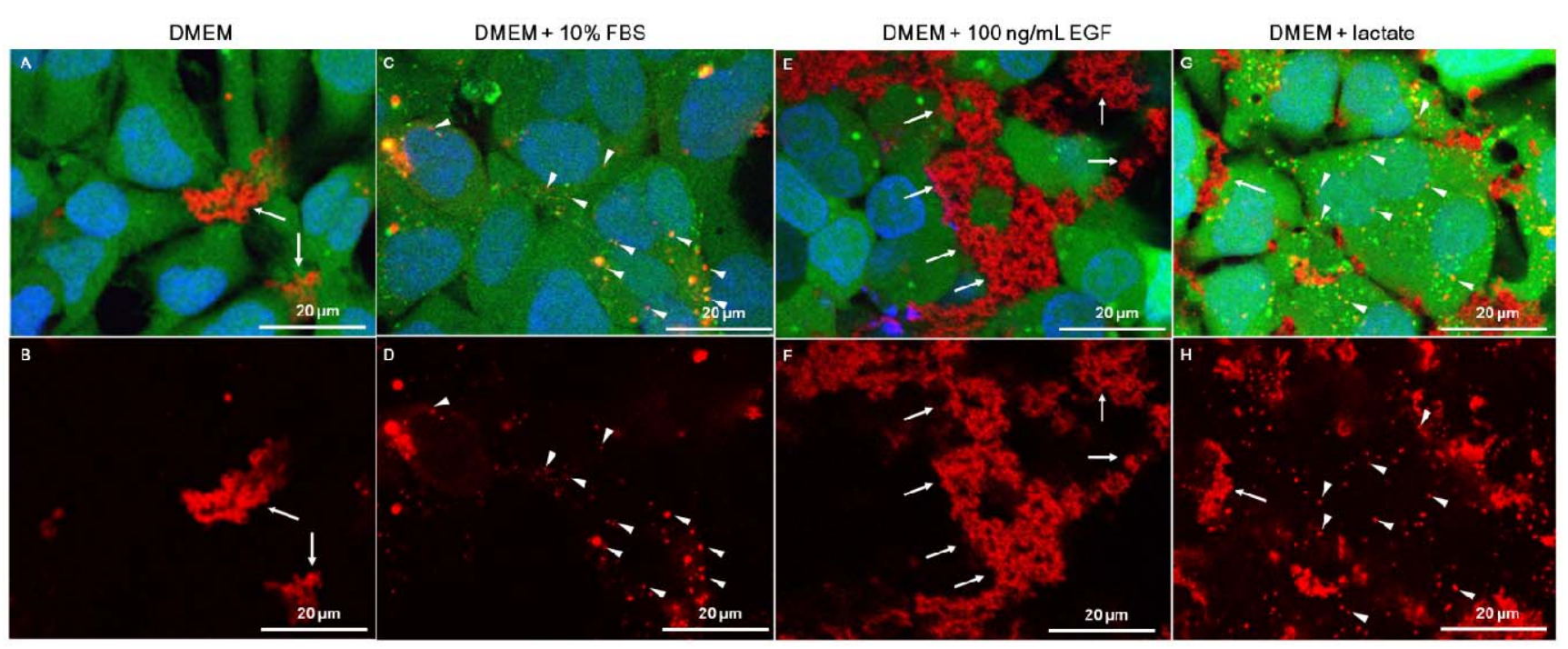

This study reports novel data showing that $\geq 2 \%$ serum promotes significant uptake of biofouled biodegradable and non-biodegradable insoluble chitosan microparticles in HEK293 cells, after enough time has elapsed to allow the particles to fully settle on the cell monolayer. RITC-chitosan particles and many intracellular vesicles had a similar diameter, suggesting that each vesicle could contain 1 or a few RITC-chitosan microparticles. This notion, together with the FACS analysis performed on cells incubated in graded serum concentrations, suggests that higher levels of serum promote cells to take up more individual particles per cell—rather than more chitosan particles per vesicle.

High-glucose media (DMEM, DMEM with serum and DMEM with EGF) all stimulated cell glycolysis, but only serum promoted significant media acidification and insoluble RITC-chitosan particle uptake. These data are consistent with a report that serum specifically stimulates mitochondrial oxidative phosphorylation and $\mathrm{CO}_{2}$ generation [47], which is acidifying through the bicarbonate buffer system (Figure 10A). These collective data suggest that serum most probably drives higher cell energetics required for membrane ruffling in macropinocytosis [48]. It is also possible that serum- 
stimulated cell metabolism helps the cell generate local acid gradients at the cell membrane that dissociate chitosan aggregates, or confer slight positive charge to particles and favor interaction of single chains with the cell membrane, and thereby facilitate uptake of membrane-bound chitosan. Biofouling of chitosan particles with anionic serum proteins could also potentially facilitate break-up of chitosan aggregates. Once internalized, as for any other macromolecular nutrient, chitosan provides the cell with an organic energy source, but may take a while to become metabolized as the label persists in intracellular vesicles for several weeks and cell passages (unpublished observations).

Particle size and cell adhesion both play a role on biomaterial uptake in serum-free media. Smaller nanoparticles of chitosan-DNA, chitosan-polyphosphate, and even serum-coated polystyrene are internalized by non-phagocytic cells under serum-free conditions [9,15,25,26,33,49]. HeLa epithelial cells show only minor uptake of individual 0.5 to $3 \mu \mathrm{m}$ diameter spherical particles after 4 hours in serum-free media, although higher uptake is seen for particles carrying a positive surface charge (amino-methacrylate-containing hydrogel particles, polyethylinimine-coated latex beads) [16,42]. Cells may be unable to internalize chitosan microparticles in serum-free media $\mathrm{pH} 7.4$ partly because the slightly electronegative salt particles have a poor capacity to bind to the cell membrane (Figure 6B). In addition, at $\mathrm{pH} 7.4$ chitosan forms high molecular weight aggregates (Figures 6A and 12E), too large to be internalized by non-phagocytic cells. Soluble individual macromolecules such as hyaluronan (negative charge) [50], dextran (neutral), and lactate acid-soluble chitosan (positive charge, Figure $12 \mathrm{G}-\mathrm{H}$ ) could enter the cell more easily by fluid-phase pinocytosis. Note that the effective concentration of chitosan at the cell surface is diminished in acidified media where half of the chitosan is in the fluid-phase, compared to media at neutral $\mathrm{pH}$ that generates $99 \%$ insoluble chitosan particles that fully collect on the monolayer surface. Tissue acidification to $\mathrm{pH} 6.5$ required for uptake of soluble cationic chitosan chains may be present only in special circumstances in vivo, in cases of hypoxia in healing wounds, or rapidly growing tumors [51].

Data generated by this study show that the volume of culture media controls the rate of uptake, because it takes longer for chitosan particles to settle in a thick layer of media. These results suggest new methods for promoting rapid chitosan particle uptake in vitro, for example, by pipetting insoluble microparticles over cells with only a thin layer of serum-containing media, or by collecting particles and cells into a loose pellet to maximize particle-cell contact. These data also suggest that the $\mathrm{pH}$ of the chitosan delivery system could have an important influence on chitosan dispersion in vivo at physiologic $\mathrm{pH}$.

Translation of chitosan for in vivo applications needs to place in vitro culture systems into perspective. Serum-stimulation of in vitro cultured cells simulates a context of wounding, where bleeding, coagulation, and edema promoting platelet degranulation are present. Serum drives chitosan uptake in vitro by mesenchymal stem cells and epithelial cells [22,27,52], and in this study, 95\% DDA chitosan was internalized more rapidly in vitro by HEK293 cells than 80\%DDA chitosan (Figure 7I). However, when implanted in vivo as microparticles formed inside a blood clot, 80\% DDA chitosan is more rapidly taken up by cells than 95\% DDA chitosan [53], namely by neutrophils and macrophages [11,12,21,54]. Targeted delivery of chitosan microparticles to non-phagocyte cells in vivo may require the use of non-biodegradable chitosan or chitosan derivatives to elude innate immune cell clearance [24]. Future design of chitosan particles that guide specific in vivo responses will require a better understanding of innate immune reactions to insoluble chitosan microparticles. 


\section{Experimental}

\subsection{Materials}

Medical-grade chitosans (80.6\% DDA, 81.5\% DDA, 94.5\% DDA, $<0.2 \%$ protein, $<500$ Endotoxin Units (EU)/g) were provided by BioSyntech (now Piramal Healthcare Canada, Laval, QC, Canada). RITC was covalently coupled to chitosan at $0.5 \% \mathrm{~mol} \mathrm{RITC} / \mathrm{mol}$ chitosan (Table 1 ) or $1.0 \% \mathrm{~mol} / \mathrm{mol}$ (81.5\% DDA) and the molecular weight determined as previously described [34]. HEK293 cells were purchased from the American Type Culture Collection (Catalog $\mathrm{N}^{\circ}$ CRL-1573, Manassas, VA, USA) and used between passage 7 and 28. Hoechst 33342, calcein AM, Dulbecco's Modified Eagle Medium with High Glucose (DMEM-H, with 25 mM D-glucose) (Gibco Product No, 12100-046, with 2.2 g/L sodium bicarbonate), and trypsin-ethylenediaminetetraacetic acid (trypsin-EDTA), and recombinant epidermal growth factor (EGF) were from Invitrogen (Mississauga, ON, Canada). Costar 6-well plates and $30 \mathrm{~mm}$ tissue culture petris, Corning $0.22 \mu \mathrm{m}$ syringe filters, and 96-well black assay FluoroNunc flat-bottom plates, were from Fisher Scientific (Montreal, Canada). Fetal Bovine Serum (FBS), rhodamine B, Dulbecco's phosphate buffered saline (PBS), L-(+)-Lactic acid solution (90\% purity), and $1 \mathrm{~N}$ hydrochloric acid (cell culture grade) were from Sigma-Aldrich (Oakville, ON, Canada).

\subsection{Photoacoustic Fourrier Transform Infrared Spectroscopy (PAS FT-IR)}

Spectral analyses were carried out on chitosans with either medium viscosity $(80 \mathrm{M}, 82 \mathrm{M}, 95 \mathrm{M})$ or low viscosity (80L, 95L) prior to RITC derivatization or RITC-82M (Table 1). Samples 80L, 80M, 95L and $95 \mathrm{M}$ were freeze-dried as an $\mathrm{HCl}$ salt conjugate while $82 \mathrm{M}$ chitosan and RITC-chitosan $82 \mathrm{M}$ were alkaline-precipitated, rinsed with deionized water to neutral $\mathrm{pH}$, then freeze-dried in free base form. Samples were stored in dessicant prior to PAS FT-IR analysis of dry powder under helium gas with a Digilab FTS6000 FT-IR spectrometer equipped with a Photoacoustic cell (MTEC Model 300 Detector, MTEC Photoacoustics, Inc., Ames, IA, USA). Samples and the background scan were performed at room temperature with a spectral resolution of $8 \mathrm{~cm}^{-1}$ using the rapid scan mode at $2.5 \mathrm{KHz}$.

\subsection{Particle Size and Zeta Potential}

A Malvern particle sizer (Nano-AS, Malvern Instruments, Worcestershire, UK) was used to determine RITC-chitosan particle size and zeta potential in DMEM and DMEM $+10 \%$ FBS. RITC-chitosan particles were formed by pipetting $10 \mu \mathrm{L}$ of $5 \mathrm{mg} / \mathrm{mL}$ RITC-chitosan into $1 \mathrm{~mL}$ of culture medium $\mathrm{pH} 7.4$ with gentle mixing, and particle size or zeta potential was measured after 5 minutes of incubation at room temperature in a closed cryovial. Size data from intensity weighted distribution were calculated as the average of 2 independent reads of the major peak. Zeta potential is reported as the mean \pm standard deviation obtained from duplicate measures of 2 independent samples prepared on separate occasions. Measures of DMEM-only showed negligible particle levels in the medium.

\subsection{Measurement of RITC-Chitosan Solubility in Cell Culture Media}

RITC-chitosan was dissolved at $5 \mathrm{mg} / \mathrm{mL}$ in dilute $\mathrm{HCl}(20.7 \mathrm{mM} \mathrm{HCl}$ for $80 \%$ DDA chitosan and $24.3 \mathrm{mM} \mathrm{HCl}$ for $95 \%$ DDA chitosan) to produce $\mathrm{pH} 5.6$ solutions with $90 \%$ degree of protonation of 
free amine groups. These solutions were $0.22 \mu \mathrm{m}$ filter-sterilized with no loss of fluorescence and stored flash-frozen at $-80^{\circ} \mathrm{C}$ as aliquots that were freeze-thawed a maximum of 3 times, as additional freeze-thaw was observed to depress fluorescence. For solubility tests, RITC-chitosan was diluted to $50 \mu \mathrm{g} / \mathrm{mL}$ in deionized water, DMEM-H pH 7.4, DMEM-H with $7 \mathrm{mM}$ lactate $\mathrm{pH}$ 6.5, or DMEM-H $10 \%$ FBS pH 7.4, vortexed, and centrifuged for $10 \mathrm{~min}$ at $15,000 \times \mathrm{g}$, room temperature, to clear insoluble particles. Rhodamine B was also dissolved at $1 \mu \mathrm{g} / \mathrm{mL}$ in the same media conditions. Media fluorescence was measured against a standard curve of 0.2 to $2 \mu \mathrm{g} / \mathrm{mL}$ rhodamine $\mathrm{B}$ (to ensure reproducibility between plates), in triplicate wells of black FluoNunc 96-well plates with a Molecular Dynamics Gemini II fluorescent plate reader (Sunnyvale, CA, USA) set at $550 \mathrm{~nm}$ excitation, $580 \mathrm{~nm}$ emission, $570 \mathrm{~nm}$ cutoff. RITC-chitosan media solubility was calculated as the ratio of the fluorescence of cleared media supernatant divided by the fluorescence in water. Results were calculated as the mean and standard deviation from three independent sample preparations.

\subsection{Flow Cytometry}

HEK293 cells were seeded at three million cells per well in 6-well plates or $35 \mathrm{~mm}$ Petri dishes and cultured as confluent monolayers overnight in DMEM with 10\% FBS. Confluent cells were used, to ensure that all chitosan particles settled in contact with cells and not with the surface of the plastic tissue culture petri. Cells were rinsed with pre-warmed DMEM and overlaid for $4 \mathrm{~h}$ with $2.5 \mathrm{~mL}$ pre-warmed DMEM or DMEM with $10 \%$ FBS, or for $24 \mathrm{~h}$ with DMEM containing $0 \%, 2 \%, 5 \%$ or $10 \% \mathrm{FBS}$, or $10 \%$ heat-inactivated serum. Heat-inactivated serum was generated by 30 minutes incubation at $56{ }^{\circ} \mathrm{C}$. Control wells received no chitosan (negative control), or $1 \mu \mathrm{g} / \mathrm{mL}$ rhodamine B. Treated wells received $25 \mu \mathrm{L}$ of filter-sterile $5 \mathrm{mg} / \mathrm{mL}$ RITC-chitosan (in dilute $\mathrm{HCl}, \mathrm{pH}$ 5.6), pipetted directly into $2.5 \mathrm{~mL}$ media and the petri agitated briefly in a cruciform fashion to distribute chitosan particles evenly over the cells at a $50 \mu \mathrm{g} / \mathrm{mL}$ final concentration. After 4 or $24 \mathrm{~h}$ of incubation in a humidified incubator at $37{ }^{\circ} \mathrm{C}, 5 \% \mathrm{CO}_{2}$, cells were labeled for $5 \mathrm{~min}$ with $2 \mu \mathrm{g} / \mathrm{mL}$ Hoescht 33342 , rinsed with PBS, treated for 5 to $10 \mathrm{~min}$ with trypsin-EDTA, centrifuged in DMEM+10\% FBS, resuspended in DMEM or PBS and kept on ice until analyzed using a MoFlo Cytometer (Cytomation, Denver, CO, USA). For different uptake experiments, the FL4 channel (530 nm excitation at $200 \mathrm{~mW}$, emission filter 580/60) was adjusted to have an appropriate dynamic range. Serum-opsonized chitosan particles were generated by incubating chitosan for $1 \mathrm{~h}$ at $37^{\circ} \mathrm{C}$ in DMEM with $10 \% \mathrm{FBS}$, followed by centrifugation to collect chitosan particles, washing in DMEM pH 7.4 to remove residual serum, and resuspended in DMEM at the same $50 \mu \mathrm{g} / \mathrm{mL}$ concentration to apply to cells. Unlabeled cells, double-positive red (RITC-chitosan) and blue (Hoechst-stained nuclei) cells, and pulse-width gated events were used to exclude cell debris, cell doublets, and free RITC-chitosan particles from the analyses. The linear relative fluorescence ( 1 to 256 ) was converted to log scale values (from 1 to 10,000) using the equation $\log X=10 * X / 64$ in order to generate the graph profiles for Figures 7 and 9 , using Microsoft Excel. The MoFlo software automatically reported the data as mean fluorescence, and percent gated cells labeled. All data were reproducible $(\mathrm{N}=3$ to $\mathrm{N}=4$ independent cultures on separate occasions, except for lactate+DMEM, $\mathrm{N}=2$ separate occasions and serum-opsonized chitosan particles, $\mathrm{N}=1$ experiment with two distinct chitosans). 
To generate cell cytospins, cell suspensions prepared for flow cytometry (at approximately $10^{6}$ cells per $\mathrm{mL}$ ) were diluted by pipetting $100 \mu \mathrm{L}$ cells into $1.5 \mathrm{~mL}$ room temperature phosphate buffered saline. Glass microscope slides cleaned with $70 \%$ ethanol to remove dust particles were placed in cytospin holders with a single funnel and a filter paper adapter. $500 \mu \mathrm{L}$ of diluted cells were pipetted into the funnel, and the cytospin (Rotofix 23, Hettich Lab Technology, Tuttlingen, Germany) centrifuged for 5 minutes at $500 \mathrm{rpm}$. Cells were allowed to air dry then imaged with an inverted epifluorescent microscope equipped with a digital camera and calibrated histomorphometry software (Northern Eclipe, Empix, Missisauga, ON, Canada) by collecting red fluorescent, blue fluorescent and low-intensity brightfield images of the same field at 20x magnification that were merged into one digital image.

\subsection{Live Confocal Microscopy}

Confluent monolayer HEK293 cells were cultured in DMEM or DMEM+10\% FBS initial pH 7.4, with or without $50 \mu \mathrm{g} / \mathrm{mL}$ RITC-chitosan $(80 \mathrm{M}, 95 \mathrm{M}, 80 \mathrm{~L}, 95 \mathrm{~L})$ or $1 \mu \mathrm{g} / \mathrm{mL}$ rhodamine B for $24 \mathrm{~h}$. Uptake of RITC-80M after $24 \mathrm{~h}$ was also analyzed in DMEM pH 7.4, or DMEM supplemented with $7 \mathrm{mM}$ lactate (media $\mathrm{pH} \sim 6.5$ ), or DMEM pH 7.4 with EGF (30 ng/mL or $100 \mathrm{ng} / \mathrm{mL}$, to promote macropinocytosis [45]), or DMEM with 10\% FBS pH 7.4. After RITC-chitosan incubation, cells were further labeled with $1 \mu \mathrm{g} / \mathrm{mL}$ calcein AM (30 min incubation, $37^{\circ} \mathrm{C}$, vital fluorescent green cytosolic stain), then with $2 \mu \mathrm{g} / \mathrm{mL}$ Hoechst 33342 (5 min incubation, $37{ }^{\circ} \mathrm{C}$, fluorescent blue nuclei) and then rinsed and placed in DMEM for confocal imaging using a Carl Zeiss LSM 510 META Axioplan 2 confocal scanning microscope equipped with a Plan-Apochromat 63x/1.0NA water-immersion objective (Carl Zeiss AG, Feldbach, Switzerland). 3D images were produced using the software Imaris (Bitplane, Zurich, Switzerland).

\subsection{Lactate and Glucose Measurements}

The YSI 2700 SELECT Biochemistry analyzer (Life Sciences, Yellow Springs, OH, USA) was used to determine the concentration of L-lactate and D-glucose in unconditioned and 24-hour conditioned cell culture media in cells cultured with or without serum, or EGF, or lactate-acidified media, and exposed or not to RITC-chitosan 80M. Data were analyzed as the mean level of L-lactate produced (i.e., final conditioned media L-lactate concentration subtracted for initial media L-lactate concentration) and depletion of D-glucose (initial D-glucose subtracted for final D-glucose) obtained from independent cell samples generated during 2 or 3 distinct cultures, with $\mathrm{N}=3$ to 5 (DMEM, $\mathrm{DMEM}+2 \%$ to $10 \% \mathrm{FBS}$, lactate, and EGF) and data shown as the mean $\pm \mathrm{SD}$.

\subsection{Statistical Analysis}

The Student's t-test was used to test the effect of serum and DDA on RITC-chitosan fluorescence in media cleared on insoluble precipitates $(\mathrm{N}=3$ to 5 distinct samples per chitosan and two chitosan types per DDA), the effect of cells and serum on media $\mathrm{pH}(\mathrm{N}=3$ to 6 readings from cultures carried out on separate occasions), rhodamine B fluorescence in culture media $v$ s. deionized water $(\mathrm{N}=3)$ and zeta potential of RITC-chitosan in DMEM $+10 \%$ serum vs. DMEM+10\% serum. One-way analysis of 
the variance of the mean (ANOVA) was used to analyze the effect of media condition on mean FL4 channel (red excitation/emission) cell fluorescence and percent cells labeled, in a population of 5,000 to 20,000 cells analyzed by flow cytometry, using Statistica software (StatSoft, version 6.1, Tulsa, OK, USA). Significance was set at $p<0.05$.

\section{Conclusions}

The chitosans analyzed in this study are acid-soluble polysaccharides that form insoluble neutral microparticles when added to standard cell culture media ( $\mathrm{pH}$ 7-7.5). In serum-containing media $\mathrm{pH}$ 7.4, non-biodegradable chitosan was 99\% insoluble, and was internalized more rapidly than $80 \%$ DDA chitosan after $4 \mathrm{~h}$ of incubation. The delay in cell uptake of $80 \%$ DDA chitosan in vitro can be explained by the slight but significantly enhanced solubility of $80 \%$ DDA chitosan in the presence of serum, compared to $95 \%$ DDA chitosan, which delayed particle precipitation onto the cell monolayers. The dose-dependent effect of serum on chitosan particle uptake, and observed media acidification specifically in the presence of serum, suggest that serum up-regulates cell metabolism required for macropinocytosis [48]. By contrast, in serum-free medium $\mathrm{pH} 6.5$, a significant $30 \%$ to $50 \%$ of the chitosan remains soluble and becomes taken up at low-levels in small intracellular vesicles under conditions of relatively low metabolism (lactated DMEM). These data suggest that soluble cationic chitosan chains can enter the cell through non-specific fluid-phase pinocytosis. This study has clarified the role of serum and media $\mathrm{pH}$ on chitosan solubility and cell internalization. Soluble chitosan chains can enter the cell through fluid-phase pinocytosis while serum-biofouled chitosan particles can only be engulfed through high energy-dependent processes stimulated by serum.

\section{Acknowledgments}

This work was supported by the National Engineering Research Council (NSERC Discovery to $\mathrm{CDH}$ ), the Canadian Institutes of Health Research (CIHR, MOP 185810 to CDH), and salary support by the Fonds de la Recherche Santé Québec (FRQS) Groupe de Recherche en Sciences et Technologies Biomédicales (GRSTB: JGM, ML, NTK) and FRSQ career fellowship award (bourse Chercheur National, CDH). We grateful acknowledge Myriam Lamarre, Jun Sun, Surendra Nimesh, Asma Baatour, Hana Ben Amara, and Vincent Darras for technical contributions.

\section{Conflict of Interest}

The authors have no conflicts to declare.

\section{References}

1. Shigemasa, Y.; Minami, S. Applications of chitin and chitosan for biomaterials. Biotechnol. Genet. Eng. Rev. 1996, 13, 383-420.

2. Berger, J.; Reist, M.; Mayer, J.M.; Felt, O.; Gurny, R. Structure and interactions in chitosan hydrogels formed by complexation or aggregation for biomedical applications. Eur. J. Pharm. Biopharm. 2004, 57, 35-52. 
3. Filion, D.; Lavertu, M.; Buschmann, M.D. Ionization and solubility of chitosan solutions related to thermosensitive chitosan/glycerol-phosphate systems. Biomacromolecules 2007, 8, 3224-3234.

4. Onishi, H.; Machida, Y. Biodegradation and distribution of water-soluble chitosan in mice. Biomaterials 1999, 20, 175-182.

5. Lin, C.W.; Lin, J.C. Characterization and blood coagulation evaluation of the water-soluble chitooligosaccharides prepared by a facile fractionation method. Biomacromolecules 2003, 4, 1691-1697.

6. Ohara, N.; Hayashi, Y.; Yamada, S.; Kim, S.K.; Matsunaga, T.; Yanagiguchi, K.; Ikeda, T. Early gene expression analyzed by cDNA microarray and RT-PCR in osteoblasts cultured with water-soluble and low molecular chitooligosaccharide. Biomaterials 2004, 25, 1749-1754.

7. Varum, K.M.; Holme, H.K.; Izume, M.; Stokke, B.T.; Smidsrod, O. Determination of enzymatic hydrolysis specificity of partially $N$-acetylated chitosans. BBA-Gen. Subjects 1996, 1291, 5-15.

8. Tomihata, K.; Ikada, Y. In vitro and in vivo degradation of films of chitin and its deacetylated derivatives. Biomaterials 1997, 18, 567-575.

9. Huang, M.; Khor, E.; Lim, L.Y. Uptake and cytotoxicity of chitosan molecules and nanoparticles: Effects of molecular weight and degree of deacetylation. Pharm. Res. 2004, 21, 344-353.

10. Usami, Y.; Okamoto, Y.; Takayama, T.; Shigemasa, Y.; Minami, S. Effect of $N$-acetyl-Dglucosamine and D-glucosamine oligomers on canine polymorphonuclear cells in vitro. Carbohydr. Polym. 1998, 36, 137-141.

11. Chevrier, A.; Hoemann, C.D.; Sun, J.; Buschmann, M.D. Chitosan-glycerol phosphate/blood implants increase cell recruitment, transient vascularization and subchondral bone remodeling in drilled cartilage defects. Osteoarthr. Cartil. 2007, 15, 316-327.

12. Hoemann, C.D.; Chen, G.; Marchand, C.; Sun, J.; Tran-Khanh, N.; Chevrier, A.; Thibault, M.; Fernandes, M.G.J.; Poubelle, P.E.; Shive, M.S.; et al. Scaffold-guided subchondral bone repair: Implication of neutrophils and alternatively activated arginase-1+ macrophages. Am. J. Sports Med. 2010, 38, 1845-1856.

13. Simard, P.; Galarneau, H.; Marois, S.; Rusu, D.; Hoemann, C.; Poubelle, P.; El-Gabalawy, H.; Fernandes, M. Neutrophils exhibit distinct phenotypes toward chitosans with different degrees of deacetylation: implications for cartilage repair. Arthritis Res. Ther. 2009, 11, doi:10.1186/ar2703.

14. Chae, S.Y.; Jang, M.K.; Nah, J.W. Influence of molecular weight on oral absorption of water soluble chitosans. J. Control. Release 2005, 102, 383-394.

15. de Campos, A.M.; Diebold, Y.; Carvalho, E.L.S.; Sanchez, A.; Alonso, M.J. Chitosan nanoparticles as new ocular drug delivery systems: In vitro stability, in vivo fate, and cellular toxicity. Pharm. Res. 2004, 21, 803-810.

16. Casettari, L.; Vllasaliu, D.; Castagnino, E.; Stolnik, S.; Howdle, S.; Illum, L. PEGylated chitosan derivatives: Synthesis, characterizations and pharmaceutical applications. Prog. Polym. Sci. 2012, 37, 659-685.

17. Malette, W.G.; Quigley, H.J.; Gaines, R.D.; Johnson, N.D.; Rainer, W.G. Chitosan: A new hemostatic. Ann. Thorac. Surg. 1983, 36, 55-58.

18. Hoemann, C.D.; Hurtig, M.; Rossomacha, E.; Sun, J.; Chevrier, A.; Shive, M.S.; Buschmann, M.D. Chitosan-glycerol phosphate/blood implants improve hyaline cartilage repair in ovine microfracture defects. J. Bone Joint Surg.-Am. Vol. 2005, 87A, 2671-2686. 
19. Onishi, H. Chitosan microparticles. J. Drug Deliv. Sci. Technol. 2010, 20, 15-22.

20. Hoemann, C.D.; Sun, J.; McKee, M.D.; Chevrier, A.; Rossomacha, E.; Rivard, G.E.; Hurtig, M.; Buschmann, M.D. Chitosan-glycerol phosphate/blood implants elicit hyaline cartilage repair integrated with porous subchondral bone in microdrilled rabbit defects. Osteoarthr. Cartil. 2007, $15,78-89$.

21. Lafantaisie-Favreau, C.-H.; Guzman-Morales, J.; Sun, J.; Chen, G.; Harris, A.; Smith, T.D.; Carli, A.; Henderson, J.; Stanish, W.D.; Hoemann, C.D. Subchondral pre-solidified chitosan/blood implants elicit reproducible early osteochondral wound-repair responses including neutrophil and stromal cell chemotaxis, bone resorption and repair, enhanced repair tissue integration and delayed matrix deposition. BMC Musculoskelet. Disord. 2013, in press.

22. Thibault, M.; Astolfi, M.; Tran-Khanh, N.; Lavertu, M.; Darras, V.; Merzouki, A.; Buschmann, M.D. Excess polycation mediates efficient chitosan-based gene transfer by promoting lysosomal release of the polyplexes. Biomaterials 2011, 32, 4639-4646.

23. Lavertu, M.; Methot, S.; Tran-Khanh, N.; Buschmann, M.D. High efficiency gene transfer using chitosan/DNA nanoparticles with specific combinations of molecular weight and degree of deacetylation. Biomaterials 2006, 27, 4815-4824.

24. Jean, M.; Smaoui, F.; Lavertu, M.; Methot, S.; Bouhdoud, L.; Buschmann, M.D.; Merzouki, A. Chitosan-plasmid nanoparticle formulations for IM and SC delivery of recombinant FGF-2 and PDGF-BB or generation of antibodies. Gene Ther. 2009, 16, 1097-1110.

25. Sato, T.; Ishii, T.; Okahata, Y. In vitro gene delivery mediated by chitosan. Effect of pH, serum, and molecular mass of chitosan on the transfection efficiency. Biomaterials 2001, 22, 2075-2080.

26. Nimesh, S.; Thibault, M.M.; Lavertu, M.; Buschmann, M.D. Enhanced Gene Delivery Mediated by Low Molecular Weight Chitosan/DNA Complexes: Effect of $\mathrm{pH}$ and Serum. Mol. Biotechnol. 2010, 46, 182-196.

27. Guzmán-Morales, J.; El-Gabalawy, H.; Hoang, M.P.; Tran-Khanh, N.; McKee, M.D.; Wu, W.; Centola, M.; Hoemann, C.D. Effect of chitosan particles and dexamethasone on human bone marrow stromal cell osteogenesis and angiogenic factor secretion. Bone 2009, 45, 617-626.

28. Guzmán-Morales, J.; Ariganello, M.B.; Hammami, I.; Thibault, M.; Jolicoeur, M.; Hoemann, C.D. Biodegradable chitosan particles induce chemokine release and negligible arginase-1 activity compared to IL-4 in murine bone marrow-derived macrophages. Biochem. Biophys. Res. Commun. 2011, 405, 538-544.

29. Al Kobiasi, M.; Chua, B.Y.; Tonkin, D.; Jackson, D.C.; Mainwaring, D.E. Control of size dispersity of chitosan biopolymer microparticles and nanoparticles to influence vaccine trafficking and cell uptake. J. Biomed. Mater. Res. A 2012, 100A, 1859-1867.

30. Ueno, H.; Nakamura, F.; Murakami, M.; Okumura, M.; Kadosawa, T.; Fujinag, T. Evaluation effects of chitosan for the extracellular matrix production by fibroblasts and the growth factors production by macrophages. Biomaterials 2001, 22, 2125-2130.

31. Usami, Y.; Okamoto, Y.; Minami, S.; Matsuhashi, A.; Kumazawa, N.H.; Tanioka, S.; Shigemasa, Y. Migration of canine neutrophils to chitin and chitosan. J. Vet. Med. Sci. 1994, 56, 1215-1216.

32. Huang, M.; Ma, Z.S.; Khor, E.; Lim, L.Y. Uptake of FITC-chitosan nanoparticles by A549 cells. Pharm. Res. 2002, 19, 1488-1494. 
33. Ma, Z.S.; Lim, L.Y. Uptake of chitosan and associated insulin in Caco-2 cell monolayers: A comparison between chitosan molecules and chitosan nanoparticles. Pharm. Res. 2003, 20, 1812-1819.

34. Ma, O.; Lavertu, M.; Sun, J.; Nguyen, S.; Buschmann, M.D.; Winnik, F.M.; Hoemann, C.D. Precise derivatization of structurally distinct chitosans with rhodamine B isothiocyanate. Carbohydr. Polym. 2008, 72, 616-624.

35. Benesch, J.; Tengvall, P. Blood protein adsorption onto chitosan. Biomaterials 2002, 23, 2561-2568.

36. Marchand, C.; Bachand, J.; Périnêt, J.; Baraghis, E.; Lamarre, M.; Rivard, G.E.; Crescenzo, G.D.; Hoemann, C.D. C3, C5, and factor B bind to chitosan without complement activation. J. Biomed. Mater. Res. A 2009, 93A, 1429-1441.

37. Thibault, M.; Nimesh, S.; Lavertu, M.; Buschmann, M.D. Intracellular Trafficking and Decondensation Kinetics of Chitosan-pDNA Polyplexes. Mol. Ther. 2010, 18, 1787-1795.

38. Duarte, M.L.; Ferreira, M.C.; Marvao, M.R.; Rocha, J. An optimised method to determine the degree of acetylation of chitin and chitosan by FTIR spectroscopy. Int. J. Biol. Macromol. 2002, 31, 1-8.

39. Cardenas, G.; Cabrera, G.; Taboada, E.; Miranda, S.P. Chitin characterization by SEM, FTIR, XRD, and C-13 cross polarization/mass angle spinning NMR. J. Appl. Polym. Sci. 2004, 93, 1876-1885.

40. Yohannes, G.; Wiedmer, S.K.; Elomaa, M.; Jussila, M.; Aseyev, V.; Riekkola, M.-L. Thermal aggregation of bovine serum albumin studied by asymmetrical flow field-flow fractionation. Anal. Chim. Acta 2010, 675, 191-198.

41. Sandoval, R.M.; Molitoris, B.A. Gentamicin traffics retrograde through the secretory pathway and is released in the cytosol via the endoplasmic reticulum. Am. J. Physiol. Renal Physiol. 2004, 286, F617-F624.

42. Gorochovceva, N.; Makuska, R. Synthesis and study of water-soluble chitosan- $O$-poly(ethylene glycol) graft copolymers. Eur. Polym. J. 2004, 40, 685-691.

43. Berger, M.; Hammer, C.H. Complement and Complement Reactions; Springer-Verlag: New York, NY, USA, 1988; pp. 4-17.

44. Ayache, S.; Panelli, M.C.; Byrne, K.M.; Slezak, S.; Leitman, S.F.; Marincola, F.M.; Stroncek, D.F. Comparison of proteomic profiles of serum, plasma, and modified media supplements used for cell culture and expansion. J. Transl. Med. 2006, 4, doi:10.1186/1479-5876-4-40.

45. Kerr, M.C.; Lindsay, M.R.; Luetterforst, R.; Hamilton, N.; Simpson, F.; Parton, R.G.; Gleeson, P.A.; Teasdale, R.D. Visualisation of macropinosome maturation by the recruitment of sorting nexins. J. Cell Sci. 2006, 119, 3967-3980.

46. Koivusalo, M.; Welch, C.; Hayashi, H.; Scott, C.C.; Kim, M.; Alexander, T.; Touret, N.; Hahn, K.M.; Grinstein, S. Amiloride inhibits macropinocytosis by lowering submembranous $\mathrm{pH}$ and preventing Rac1 and Cdc42 signaling. J. Cell Biol. 2010, 188, 547-563.

47. Ceriotti, L.; Kob, A.; Drechsler, S.; Ponti, J.; Thedinga, E.; Colpo, P.; Ehret, R.; Rossi, F. Online monitoring of BALB/3T3 metabolism and adhesion with multiparametric chip-based system. Anal. Biochem. 2007, 371, 92-104.

48. Swanson, J.A.; Watts, C. Macropinocytosis. Trends Cell Biol. 1995, 5, 424-428.

49. Ehrenberg, M.S.; Friedman, A.E.; Finkelstein, J.N.; Oberdorster, G.; McGrath, J.L. The influence of protein adsorption on nanoparticle association with cultured endothelial cells. Biomaterials 2009, 30, 603-610. 
50. Greyner, H.J.; Wiraszka, T.; Zhang, L.S.; Petroll, W.M.; Mummert, M.E. Inducible macropinocytosis of hyaluronan in B16-F10 melanoma cells. Matrix Biol. 2010, 29, 503-510.

51. Gratton, S.E.A.; Ropp, P.A.; Pohlhaus, P.D.; Luft, J.C.; Madden, V.J.; Napier, M.E.; DeSimone, J.M. The effect of particle design on cellular internalization pathways. Proc. Natl. Acad. Sci. USA 2008, 105, 11613-11618.

52. Corsi, K.; Chellat, F.; Yahia, L.; Fernandes, J.C. Mesenchymal stem cells, MG63 and HEK293 transfection using chitosan-DNA nanoparticles. Biomaterials 2003, 24, 1255-1264.

53. Lafantaisie-Favreau, C.-H.; Sun, J.; Chen, G.; Rusu, D.; Poubelle, P.; Hoemann, C.D. Implication of mast cells in chitosan/blood implant induction of in vivo chemotaxis and alternative macrophage activation. Presented at Canadian Connective Tissue Conference, Montreal, Canada, 27 May, 2011.

54. Kas, H.S. Chitosan: Properties, preparations and application to microparticulate systems. J. Microencapsul. 1997, 14, 689-711.

Sample Availability: Samples of RITC-95M and RITC-80M chitosan are available from the authors.

(C) 2013 by the authors; licensee MDPI, Basel, Switzerland. This article is an open access article distributed under the terms and conditions of the Creative Commons Attribution license (http://creativecommons.org/licenses/by/3.0/). 